\title{
Reto Foellmi Recommends "Firms in International Trade" by Andrew B. Bernard, J. Bradford Jensen, Stephen J. Redding and Peter K. Schott
}

\author{
Reto Foellmi
}

\section{DThe findings of Bernard et al. show that the resil- ience to shocks and the ability to sustain inequali- ties are central elements for successful economies in the future. It is interesting to explore what char- acteristics in economics and policy help in attain- ing these goals.}

Since World War II, we have seen an ever-increasing amount of international exchange of goods, services, labour and capital. In politics and society alike, the potential effects of this phenomenon are eagerly discussed more than ever. However, knowledge is still scarce how this important feature of globalization affects the functioning of markets and firms on a smaller scale.

In a succinct and easy-to-read summary of their own and some other work, Bernard et al. (2007) highlight which actors actually trade. Maybe different to general views, trade is still a rare phenomenon. What is not too surprising is that only a small share of firms engage in exporting. In most OECD countries, less than $10 \%$ of firms are exporters. Even if we account for the fact that exporters are on average double as large as non-exporters, most workers are employed in

\section{R. Foellmi $(\bowtie)$}

SIAW-HSG, University of St. Gallen, St. Gallen, Switzerland e-mail: reto.foellmi@unisg.ch 


\section{R. Foellmi}

domestic-only firms. Controlling for different branches, exporters are always a minority even in export-oriented sectors like machinery or pharmaceuticals.

Comparing exporting and non-exporting firms, exporters are very different. On average, they are larger and much more productive, the latter holding true even if you control for size. Higher productivity is associated with the fact that exporters attract better-skilled workers and pay higher salaries. What I found most surprising is that inequality between firms is very pronounced amongst the group of exporters too. Bernard et al. document that international trade is extremely concentrated across exporting firms. In 2000, the top $1 \%$ of trading firms by value accounted for over $80 \%$ of the value of total trade. However, they employed only a share of $14 \%$ of all workers amongst exporters. Likely, concentration is currently more pronounced as a result of the winner-takes-all features of ICT technology.

This basic insight about firm structure bears an important implication on the effect of trade liberalization — or on the opposite-what could happen if trade barriers were rebuilt. Since firms are so different, integration in larger markets is likely to lead to large shifts in employment. The more productive, innovative firms will attract workers and potentially migrants. Less productive firms and sectors will shrink and possibly leave the market.

These findings by Bernard et al. link globalization with structural change. Consequently, we learn more about the interplay between trade, structural change and inequalities between individuals and firms. In the past, these issues played a minor role in economic science. To judge the feasibility of open markets, at least in democratic societies, it seems central to understand these phenomena better.

In my view, the ability of an economy to allow structural changes is central to sustained growth and - eventually_-to maintaining a stable democracy with free markets. The big changes by new technologies and globalization force the economy to adapt at a high speed because the underlying firm and sectoral structure are crucially affected. On the opposite, growth prospects are doomed if a political process, such as capture by rent-seekers, tries to block these changes.

The findings of Bernard et al. have brought these arguments back to the table. Resilience to shocks and the ability to sustain inequalities are central elements for successful economies in the future. It is interesting to explore what characteristics in economics and policy help in attaining these goals.

\section{Literature}

Bernard, A. B., Jensen, J. B., Redding, S. J., \& Schott, P. K. (2007). Firms in international trade. Journal of Economic Perspectives, 21(3), 105-130. 